\title{
Intertextual and Intercultural Dynamics between Roman Comedy and Latin Love Elegy
}

\author{
Maria GIANNAKI
}

University of Paris Sorbonne IV

The purpose of this presentation is to examine the intertextual and intercultural dynamics upon which the reception of Roman Comedy in Roman Love Elegy is based, focusing on Propertius. My objective is to show that, unlike the researchers who support that Latin love elegy remains uninfluenced by Plautus and Terence's comedies ${ }^{1}$, this poetic genre draws and exploits material even from Roman Comedy. The difficulty arises as we set the following questions: which comedy has influenced Propertius? The Greek or Latin comedy ? For it is only the name of Menander $^{2}$ that appears when we read the elegies (III. 21 ; IV, 5 ). Why does the poet choose to draw material from comedy? How does this material serve him? Our purpose is not to add all the parallels between Propertius and the Roman Comedy, although we have been able to do this in some instances, but rather we shall try to follow the didactic thread as it appears in the mass of varying parallels already collected and to bring out new aspects of these parallels.

The ars amatoria which is so prominent in Roman elegy is also a reflection of real life and was not applicable to the heroic age. The ars amatoria was developed in comedy, and comedy is therefore the ultimate source of this element, including erotic teaching, in Roman elegy. This is the general truth, but the channel by which comedy exerted this influence on Roman elegy is by no means determined ${ }^{3}$.

It is a fact drawn from studies that Propertius has used the already existing literary tradition, both Greek and Latin, epos, tragedy, comedy and 


\section{- Intertextual and Intercultural Dynamics between Roman Comedy and Latin Love Elegy}

Greek elegy, in order to compose his own poetry. The manipulation of this material has been innovating as Propertius, through expanding and mixing the boundaries between the literary genres, exceeds and incorporates them creatively in this new poetic genre.

Some features in Propertius's work are not simply pleasant, amusing or voluntarily ridiculous. It is the comic world with its characters and its characteristic positions that offers the background to elegy and participates indirectly in the construction of the meaning. In my opinion the poet has adopted a clever way in which, through comic allusions, wages a literary war so as to divert and separate his poetry from the other universal models and place in the very center of his work his beloved Cynthia. His famous recusatio, in which he places his poems directly in the poetic level of Callimachus and Philitas, is also happening indirectly through inserting comical elements in his elegies. By definition comedy is the $\mu i \mu \eta \sigma \iota \varsigma^{4}$ of the more humble people and is considered to be a poetic gender inappropriate for exalting heroes and heroic deeds. Propertius who systematically serves love elegy according to Callimachean imperatives, does not hesitate to imbue comic elements into his writing, thus creating his own poetry which is a game of texts and genres (intertextuality, intergenericity). Besides elegy does not consider itself to be of the higher literary genres (despite the fact that while analyzing it we witness its complexity as it contains almost every poetic genre). Propertius in III.5.23-46 wishes to save his more serious thoughts and studies for when he will grow old and will no longer be in love. That way elegy is placed below epos and tragedy although it may seem to be above mime and satire. The elegists love to name their verses nugae or lusus ${ }^{5}$.

At the same time the poet seems to be fully aware of the social purpose of his art. This becomes clearer as one accepts the fact that the funny-comic element is a social product by itself. Nobody would create jokes just for himself, that is jokes that are not meant for others to hear. 


\section{Maria GIANNAKI}

They are a specific means of connection between the creator and his audience and they serve a specific purpose. Propertius, by deleting his own triumph as a poet, devalues his contemporary Roman institutions and brings forth the biotheoretical dilemma between poetry and the politics the Augustan poets were facing.

The poet writes his works in a time of religious, moral and political crisis; he creates his own elegiac code against the existing disorder and seeks a haven to escape to. Through his allusions to comedy he wants to make his audience understand that his elegies are brimming with messages that go even beyond the comic. The aim of the poet, as well as his peers, was, through humour, to say not only things that are funny but also things that are serious - a duality that is a characteristic of most of his poems. He believes that the role of a poet is equally artistic and socio-political.

The underlying presence of elements that belong to comedy is one of the basic motifs of irony towards a mischievous poet who declares in this way that the text is not to be taken literally. According to J.P.Boucher ${ }^{6}$, the poet in order to define his work is borrowing motifs or scenes that appear frequently in New Comedy or epigram but are strange to Propertius's elegy. The poet puts his text, discreetly but clearly, in the tradition of New Comedy, that became known in Rome through Naevius, Plautus and Terence. The poet announces this relation between elegy and comedy in such a way as to show that it is not just an inheritance, inferior or objective, but a correlation that carries the meaning that is composed diligently by the poet in order to be better understood. The Roman elegy resumes the argument of New Comedy, which is the triumph of love over family and social restrictions by means of a cunning slave, of the triumph of guile over power, of the triumph of youth over old age.

The identification of his love and his poetry allows the elegiac poet to modulate on the one hand the subject of love that opposes the social and family conventions, and on the other hand the subject of the elegiac poetry 


\section{- Intertextual and Intercultural Dynamics between Roman Comedy and Latin Love Elegy}

that is mistreated by aesthetic conventions, a theme that is the foundation of New Comedy.

In comedy Senex the father of Iuuenis is the incarnation of these conventions, and he does not agree with his son's passion. Propertius appears to be an orphan without a father but does not quit in attributing a role (III.24.9): the very classic patrii amici ${ }^{7}$ are trying to pull the poet away (avertere) from his mistake. According to P. Grimal these are the Augustan laws that are trying to put an end to these scandalous loves to their audacious and provoking presence in elegy. A typical example is elegy II. $7^{8}$ which describes Propertius's joy after the abolition of an Augustan law ${ }^{9}$ that would force him to end his affair with Cynthia, since a marriage between a man of the higher class, such as Propertius ${ }^{10}$, and a moral-free woman was forbidden. As a consequence love dared not worry about social classes according to Paul Veyne ${ }^{11}$. Here is the similarity between elegy and comedy since elegy gives the sense of an elegiac provocation which breaks the taboo and violates the strict rules of the stature legal acts.

The elegiac puella has her literary ancestry in New Comedy's meretrices. She is a very expensive prostitute who owns property and slaves. Both in Elegy and New Comedy women look out for themselves and their interests very actively. While the men acknowledge the puella's independence and can often perceive her agency, they never know for certain what the puella is thinking or desiring, and their inability to know is what destabilizes them ${ }^{12}$. The social status of these women puts them beyond the control of any man. They are not the subject of negotiation between men, they cannot be purchased and owned and they cannot be married and absorbed into domestic possession ${ }^{13}$. Thus we see that the social status of the elegiac mistress provides a connection between the meretrices of Roman New Comedy and the elegiac puella ${ }^{14}$.

As it is known, the elegiac poets used to give to their loved ones aliases according to the poetic custom. There are two possible real names 


\section{Maria GIANNAKI}

behind the alias «Cynthia»: according to Apuleius (Apol.10) one of them is Hostia $^{15}$ while the other one is Roscia, as J.-P.Boucher ${ }^{16}$ suggests. This name comes from Roscius, an ancestor of Cynthia and a great comedian of that time from Lavinium, where Propertius met his beloved (elegy IV.8). It is possible that this choice was made to show that Propertius was quite familiar with the comedians work and with Roman comic esprit.

The elegiac poet embodies first of all the comedy's love-stricken teenager, as indicated by Propertius in elegy I.2, where the duality of Propertian inspiration is underlined. According to M. Hubbard ${ }^{17}$ «the subject, the undesirability of expensive dress and make up, is one that erotic literature derived from New Comedy, and here, as often in similar poems, Propertius deliberately gives his language a colloquial flavor that reminds us of this genesis and is in piquant contrast with other phrases of a higher stylistic level». The position of the poet on the women's excessive grooming is common both in Elegy and Comedy. Cynthia's abundant makeup and elaborate hairstyles are criticized because they suggest she seeks new lovers (I.2), and expensive clothing and jewellery are gifts that grant access to a puella's household (II.16). Propertius in his elegy II.18.23-26 shows his indignation at painted cheeks and claims $»$ Do you still in your madness imitate the painted Britons and play the wanton with foreign dyes upon your cheeks? All beauty is best as nature made it: Belgian rouge is shameful on a Roman face ${ }^{18}$ ». This position coincides with the spirit of Plautus in the third scene act I of Mostellaria where the servant Scapha assures Philematium that she is more beautiful when she is natural ${ }^{19}$. In another elegy (III.13.8) Propertius offers a moralizing passage against luxuria in a poem complaining that women expect to receive expensive luxury imports in exchange for their favor ${ }^{20}$. The premise of this poem hews to a Roman moral tradition that links the consumption of luxury goods and imported foreign culture with softness, mollitia, and the failure of traditional Roman virtues ${ }^{21}$. By adopting this cultus Cynthia becomes a 


\section{- Intertextual and Intercultural Dynamics between Roman Comedy and Latin Love Elegy}

meretrix as the poet says «as a girl determined to meet a new lover looking her best».

Comic elements much like those that are usually found in comedies are spread throughout Propertius I.3, through comparing themselves with mythological characters. The poet develops a typical comedy scene: the young man visits in the middle of the night the girl, who is the object of his desire. In the beginning we see the very first amusing effect when the drunken poet returns to the sleeping Cynthia and instead of the idealized version of her that he has created in his mind, he faces her true aggressive nature as she wakes up. After spending an ambiguous night in the city, the potentially unfaithful poet has his mind filled with suspicions that Cynthia may have been cheating on him as well. As he gazes upon her, the drunken poet mentally puts himself in Perseus' place when the hero fell in love with Andromeda the moment he laid his eyes on her. It is indicated that the poet is lusting for Cynthia's body but fearing her aggressive nature, much like a Maenad, and her verbal assault upon waking he reconsiders his sexual advances on her. According to S.J.Harrison ${ }^{22}$, Propertius I.3 is a comic study of the poet's drunkenness and of his fears of the puella's infidelity. It is comic rather than tragic or pathetic because the poet's fears and suspicions are allowed to emerge from a witty interpretation of the myths describing the sleeping puella, and because the reader is fully aware that those fears are quite possibly unfounded, and that even if well-founded they are likely to be hypocritical for a poet who has been spending his evening in town. The poem is thus perceived as witty, entertaining and psychologically interesting; as one of the first poems in Book 1 it also sets the agenda for the relationship between poet and puella, one of stormy passion but described in a manner that aims to amuse rather than to move the reader.

One of the most vivid images of obstruction painted by the love elegists is the lover's lament behind a locked door of his domina, 


\section{Maria GIANNAKI}

traditionally referred to as the paraclausithyron. The locus classicus for the name is Plutarchus Amatorius $753 \mathrm{~b}^{23}$ : «Who, then, prevents the reveling before the house, the singing of the complaint before the closed door». This theme became common in Greek poetry and comedy and accordingly entered Roman literature via the comic vehicle. Roman comedy developed directly from Greek New Comedy and Plautus and Terence included such scenes of the locked-out lover in their plays ${ }^{24}$.

Plautus introduces a number of Roman elements to the paraclausithyron in the Curculio. The most important of these elements is the address of the lament to the newly personified door, apparent when Phaedromus begs the doors to open:

«Come, festive doors, drink;

Drink, make yourselves willing, propitious for me» ${ }^{25}$.

He later reproaches the doors for betraying him and directs his rage not at the girl, but at the doors. In the same work $^{26}$ we see a young lover and his servant storming the house of his beloved. The lover fulfills his desire by bribing the janitor with wine in order to allow his girl to come on stage. This motif is rediscovered in the Augustan era by the elegiac poets who willingly make it an emblem of their kind. In Roman Elegy of Propertius $^{27}$ the door, obdurate and unyielding, is apostrophized, flattered and treated with violence ${ }^{28}$. A lover in front of a shut door is a very familiar theme from Hellenistic epigrams and Roman elegy because it represents the obstacle between the lover and his beloved as well as the boundary between what the audience can and cannot see $^{29}$. Also the doors of the house demarcated the boundary between the public and private sphere. The closed house doors could be used to represent the chastity of the wife ${ }^{30}$.

A complete novelty ${ }^{31}$ is Propertius' decision in the elegy I. $16^{32}$ to embed the lover's actual paraclausithyron, which is addressed to the door, in a monologue spoken by the door itself. By including this theme the poet 


\section{- Intertextual and Intercultural Dynamics between Roman Comedy and Latin Love Elegy}

intends to mock the topos of paraclausithyron and makes the elegy I.16 a criticism of the elegiac protocols and values. Propertius not only encodes an understanding of the elegiac genre and its principal characters but also he opens the door, so to speak, to a critique of that viewpoint ${ }^{33}$. The door laments the present low-life comings and goings of lovers and the ill-fame they bring the house, in contrast to the lofty moral tone of ancient private and public virtue that characterized the house before. A literary joke seems to be woven into the poem's texture at the line 15 of the same elegy ${ }^{34}$. The door's own complaints provide examples also of the wider symbolism of the limen in Roman culture ${ }^{35}$. According to Copley ${ }^{36}$, «Propertius in this elegy has written the definitive paraclausithyron and has made it say all that it could be reasonably expected to say, and has gathered together in one poem the essential facets and features of a literary and erotic tradition some seven hundred years long». In Roman Comedy, where the themes of the locked-out lover and the paraclausithyron were at home before they migrated to elegy, there is very frequent reference to the noise made by door posts turning in their sockets as the door is opened ${ }^{37}$. Plautus characteristically makes jokes about the convention: at Poenulus 609-610 ${ }^{38}$ the door breaks wind, at Curculius $^{39}$ one of the characters gives the doorpost a drink of water to keep it quiet and at Curculius $87-95^{40}$ the doorpost speaks. Not only is Propertius' door not allowed to be opened and thus to speak but it is not even allowed to have its own silence while shut respected «to have peace and quiet ${ }^{41}$. Propertius also does not hesitate to use the theme of paraclausithyron in order to define his elegy: in III.3.47$50^{42}$ he presents the elegy as a manual of seduction ${ }^{43}$.

The limen as a cultural symbol is a commonplace in Propertian elegy and comedy. In elegy II.6. the early love-affair is often associated with the loved one's house-door, around which eager suitors concourse. The conceptual idea is the limen or threshold of the house where Cynthia lives. The poem begins with a description of the limina of three famous 


\section{Maria GIANNAKI}

courtesans Lais, Thais and Phryne. We are in no doubt to imagine these as observed in countless scenes from Greek and Roman comedies, at least this seems to be the effect of the epithet Menandrean II.6.3., and from the many representations of Phryne in ancient $\operatorname{art}^{44}$. The idea of the limen is of course important in Roman concepts of marriage. The threshold protects the house and the faith of those in it; one should not need a guard, as Propertius points out. In this way the poet suggests the social situation of the time through an image that is a part of comedy. He inserts comic elements about a serious matter such as that of the society because his poetry follows the dictates of Callimachean imperatives $\dot{\varepsilon} \gamma \dot{\omega} \delta^{\prime} \varepsilon \ddot{\eta} \eta V$ ou $\lambda \varsigma \alpha \chi \dot{u} \varsigma, \dot{o}$ $\pi \tau \in \rho o$ \& $/ \varsigma^{45}$. The sad state of Cynthia's threshold is indicative of the sad state of Roman morality.

Also the conventional figure of the exclusus-amator is an element familiar in classical comedy, elegy, epigram or lyric. This is the motif of the «locked-out lover» which recurs in many elegies of Propertius and we indicatively mention some of them I.3.10, I.3.36; I.4.22, I.5.20, I.18.24, II.7.9, III.17.12, III.23.12., IV.3.47. In I.16 the lover, complains that the door is unmoved by his prayers ${ }^{46}$, he imagines that his mistress is inside with someone else ${ }^{47}$ and at the end he tells how many times he has sung to this door and even kissed the steps ${ }^{48}$. Another elegy which is worthy of our attention and concerns the theme of exclusus-amator is IV.9 $9^{49}$. It is worth noting that the IV.9 elegy is a light elegy with enough comic elements ${ }^{50}$ about why women were excluded from the ceremonies in honor of Hercules in the sanctuary of Ara Maxima. Very characteristic is the episode where Hercules, in an exclusus amator role this time, is thirsty and tries to convince the priest to let him be quenched by the source of the sacred invoking the feminine services he offered to Omphale ${ }^{51}$. The speech of Hercules is more fruitfully and directly comparable to that of an exclususamator. When the hero starts his speech at verse 32, he casts his suppliant 


\section{- Intertextual and Intercultural Dynamics between Roman Comedy and Latin Love Elegy}

words «before the doors» (ante fores), an expression that often introduces the paraclausithyron. With this comic appearance of Hercules, Propertius presents him to be degraded from being a demigod to an elegiac amator.

At the same time the pattern of miser amator, poor lover, used by Propertius at the very first elegy of the first book in the first line ${ }^{52}$ had cropped up often in Roman Comedy. Characteristics are the examples encountered in the works of Plautus Mercator 588-590 53 , Curculio 187$188^{54}$, Miles Gloriosus 1250-1253 ${ }^{55}$ and of Terence Eunuchus $98^{56}$, Andria $243^{57}$. Another motif common in elegy and in Roman Comedy is the idea of love as a disease of the mind. Thus in the first Elegy of the Monobiblos Propertius refers to mental illness - furor ${ }^{58}$ that follows love. With the first meaning, cupidinibus ${ }^{59}$ takes on something like the meaning of Cupid's arrows. With the second cupido is the disease and the pain therefrom. With the same use this word is found in Plautus Mercator ${ }^{60}$ and Terence Andria $^{61}$. In the same elegy Propertius presents Milanion ${ }^{62} \mathrm{mad}$ with love too. In describing him as amens, insane, the poet evokes the pun in Latin on amans, in love, and amens, insane, as found also in Mercator $^{63}$ of Plautus and Andria ${ }^{64}$ of Terence. The symptoms of love are evident in the verses $21-22^{65}$ of the same elegy where Propertius feel inferior partner and wants to get better by exchanging circumstances with the dominant one, Cynthia. He wants witches to make Cynthia to feel the passion that grips him. Within this prayer Propertius sustains again a metaphor of madness as a disease. A locus communis is created between Propertius ${ }^{66}$ and Plautus Cistellaria $^{67}$, Mercator $^{68}$ and Persa ${ }^{69}$.

Violence against the puella is common trait of the elegiac lover as the poet puts it at the heart of various comic-tragic episodes ${ }^{70}$.The crises of erotic jealousy and quarrels occasionally ended up in skirmishes between lovers, which however did not exceed the limits of a few couplets, those who need to renew the erotic feeling. Similar events unfolded also in Roman Comedy. In Plautus Bacchides ${ }^{71}$ Cleomachus, the captain, says : 


\section{Maria GIANNAKI}

«There is no amount of money if I had rather make to-day than surprise him with her in his arms, so that I may slay them both !». Another example is found in Cistellaria ${ }^{72}$ «May all the gods, great gods, small gods, and platter gods, too, prevent my kissing Selenium so long as she and I exist, unless I butcher you and your daughter and my own self this very day - and then tomorrow at early dawn murder you both - yes, by heaven and at my third assault exterminate your whole household - unless you send her back to me!». In Truculentus ${ }^{73}$ «Shall I endure to see her hug another man before my very eyes? Good Lord, I'd rather be dead this day! Hands off that man, minx, if thou be not minded that ye both should die by this my hand and mighty blade! Phron: No bambullying, soldier man, I advise you, if you want to be loved. Only gold, not iron, Stratophanes, can scare away my affection for this lad».

In the Roman elegy waggish ancillaries were never absent from similar extremes of the Propertian lover against the elegiac puella. The revenge for infidelity may include a few scratches on the face and destruction of the hairstyle ${ }^{74}$ until the «elimination» of

the lover from poetry ${ }^{75}$. Under other circumstances, the «use of force» in a love quarrel leads the elegiac scenario to completely different direction, contributing to the revitalization of the relationship ${ }^{76}$.

In comedy the role of erotic teacher is often assigned to a lena, meretrix, or even an adulescens. The activity of the procurer is a distinguished chapter in the Greek and Roman tradition. The «literary » raise and introduction of the figure of «lena» in Roman elegy forms a commonplace between elegy ${ }^{77}$ and comedy. Lena's task is to initiate her protégé to the secrets of profitable love. It's not the poet anymore he who will introduce puella to love. The teaching of love is realized by the procurer, who becomes an equal preaceptrix amoris. The role of this procurer has deep roots in the New Comedy and possibly in the Mime of Heronda, and consequently in Roman Comedy ${ }^{78}$. In New comedy of the 


\section{- Intertextual and Intercultural Dynamics between Roman Comedy and Latin Love Elegy}

Hellenistic and early Roman period the young lovers often come up against erotic tricks, behind which were typically several procurers that promoted women to economically suck men dry. The squandering of wealth of the rich lover from the immediate family of his mistress is found in Plautus Asinaria $^{79}$, Mostellaria ${ }^{80}$ where the lover suddenly intervenes to the indoctrination of a young courtesan from an old procurer ${ }^{81}$. Of course, this materialistic attitude of the lover comes into conflict with the ideal of the spirit, which is embodied by the elegiac poet - Lover ${ }^{82}$.

The black tooth of the old woman appears in Roman Comedy at Plautus Mostellaria 274-27783; and it is at Propertius IV.5.68 ${ }^{84}$ (Acanthis). Acanthis ${ }^{85}$ tells the puella to act drunk if her current boyfriend is drunk and mirror his behavior, in the manner of a Menandrian courtesan. Her discourse turns myth into everyday material and, rejects myth and tragedy from comedy, with an explicit emphasis on that genre and commendation of the «modern» culture it reflects (mundi, pretiosa) ${ }^{86}$. The choice of Thais is not hazardous. She incarnates a persona - literary symbol borrowed from the comedy and not a person of the modern era ${ }^{87}$.

Apart from the caricature-like delineation of the characters, there is always a structural irony which is the supposed obstacles, that the specific characters raise between the lover and puella, and function, in a metapoetic level, as motives of the elegiac discourse.

At the end, the appearance of Vates-Horos in the last book (IV.1.) of Propertius is an element of elegy inspired by comedy. The divine characters are presented as ridiculous. Plautus in his Rudens ${ }^{88}$ mocks their long hair and in Truculentus ${ }^{89}$ claimed that they are fighting themselves in the middle of their false seizures. In Propertius Horos is an astrologer prophet and his name may be derived from the Greek ö $\rho \varsigma$, which means 'boundary, limit' and is used to designate the boundary stone that divides pieces of property. The boundary stone is used to mark not only private property lines but also the limits of public properties ${ }^{90}$. With this 


\section{Maria GIANNAKI}

hint and the possible etymology of this strange Greco-Egyptian figure street astrologer Propertius brings the issue of boundaries in elegiac poetry: these are limits on the literary genres that are used to create the elegy, also limits that are put between the public and the author, and finally, probably, limits between the poet and his beloved as compared to the limits that are put by the door and the limina (see the motif of paraclausithyron). Horos' first words to Propertius concern the elegist's transgression of limits ${ }^{91}$. Also Horos' himself expresses a particular interest in boundaries in his recollection of Propertius's personal origins ${ }^{92}$. Finally, in order to convince Propertius not to force his inspiration, Horos recalls these words the way that is his :

\section{at tu finge elegos, fallax opus: haec tua castra! scribat ut exemplo cetera turba tuo ${ }^{93}$.}

This use of fallax by which Propertius describes the elegy is not a coincidence since it is the same adjective that characterises in Rome the servus, the deceitful and crafty slave of comedy ${ }^{94}$. Plautus in Amphitryon through Mercury returns to the announcement of the tragoedia ${ }^{95}$. Mercury announces a mixed work, a commixta tragico comoedia. The test, according to Plautus, is the presence of a slave, or rather the fact that it is a slave who takes the first or one of the leading roles. There is also an evolutionary step, as always with Propertius, between sense and meaning: the hero of the elegy is a slave, a servus amoris. According to Propertius elegy is tricky: it is "disingenuous" like the slave of Comedy and the elegiac poet, in his stage, who is inspired by another Umbrian poet, Plautus or Terence, whose prologues were the origins of the literary figure, in Rome, of the poet who is justified. Thus, the elegiac poet proves the legitimacy of his art and his artistic choices ${ }^{96}$.

We conclude that the theatrical comic frame offers a frame of reception and understanding of the elegy. The originality and scandalous character of elegiac love, in fact, is understood only through the relevant 


\title{
- Intertextual and Intercultural Dynamics between Roman Comedy and Latin Love Elegy
}

\author{
situations in comedy. According to P. Grimal ${ }^{97}$, a propos the first elegy of \\ Propertius, the elegiac poet transfers in real life a situation that Terence \\ made us accustomed to: a young man, overwhelmed by love for a \\ courtesan, renounces all that is not love. But that which in theater is but a \\ game, here turns to a tragic reality. Thus this relation between elegy and \\ comedy gives meaning to an elegiac "challenge" by breaking taboos and \\ defies the strict rules of moral statutory acts ${ }^{98}$.
}

\section{Notes}

${ }^{1}$ G.Luck, The Origin of the Latin Love Elegy, ed.2, London, 1969:35. «I maintain that the influence of Menander, Plautus and Terence can be disregarded, at least in the case of Tibullus and Propertius; that there is no evidence which would force us to derive one literary genus from the other, and that every single love - elegy is intelligible and meaningful to us without being illustrated by parallels from the comic poets». Luck bases its theory on the fact that the elegies of Tibullus and Propertius, as poetae docti, were founded on an extensive reading which included the Greek epic, the tragic and lyric poets, and the works of the Alexandrians and so they were directed at an educated audience. On the other hand, Plautus and Terence did not address themselves to the same kind of audience as the poetae docti. The playwrights wished to entertain and they required no particular knowledge of mythology and literature beyond what everybody knew.

${ }^{2}$ According to G.Anrnott, The Modernity of Menander, Greece and Rome 22, 1975:140155 , there is a device which the ancient comic dramatist Menander used to give unity and continuity to the scenes in his plays. Menander repeated at the beginning of scenes words and themes which had been used also at the end of the previous scenes. This modern menandrean technique influenced the Hellenistic poets, who in turn influenced Augustan Poetry. F.Cairns has observed its use in Tibullus, although he does not elaborate very much, since the main concern there is ring-composition (F.Cairns, Tibullus : A Hellenistic Poet at Rome. Cambridge: Cambridge UP, 1979:192). In a detailed and= $=$ thorough study, J.L.King, Studies in Verbal Repetition in the Monobiblos of Propertius Diss.U. of Colorado, 1969:273, has traced the elaborate patterns of verbal repetition in Book I of Propertius and has shown that such repetitions are integral parts of the poem in that book and also integral to the structure of the book as a whole.

3 A.L.Wheeler, «Erotic Teaching in Roman Elegy and the Greek Sources» in Classical Philology p .444., Vol. 5, No. 4, Oct., 1910: 440-450.

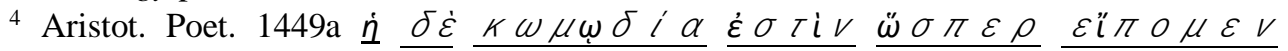

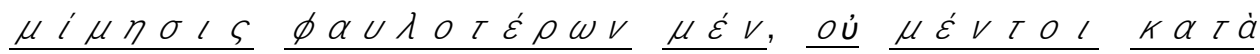




\section{- Intertextual and Intercultural Dynamics between Roman Comedy and Latin Love Elegy}

Classique, t.II, Fondation Hardt, Vandoeuvres-Geneve, 1956 who consider her as a meretrix based on elegies I.16, II.9, II.16, III.24.

${ }^{15}$ J.P.Boucher, Etudes sur Properce, 1965:461-462. The same theory is adopted by F. Della Corte, «Doctus Roscius», Studi G. Monaco, Palerme, 1991:795-799.

${ }^{16}$ J.P.Boucher 1965,461.

${ }^{17}$ M.Hubbard, Propertius, London, Duckworth 1974: 22.

${ }^{18}$ NUNC etiam infectos demens imitare Britannos, ludis et externo tincta nitore caput? ut natura dedit, sic omnis recta figura est: turpis Romano Belgicus ore color.

${ }^{19}$ Mostellaria 262-264 :

PHILEM. Tum tu igitur cedo purpurissum. SC. Non do. scita es tu quidem. nova pictura interpolare vis opus lepidissimum? non istanc aetatem oportet pigmentum ullum attingere, neque cerussam neque melinum, neque aliam ullam offuciam. «Phil.: Well, then give me the rouge.

Sc.: No, I won't. Lots of sense you show! You want to daub fresh paint on a perfectly lovely picture? Girls of your age shouldn't touch a bit of colour, or ceruse, Melian cream, or any other cosmetic».

${ }^{20}$ Inda cavis aurum mittit formica metallis, et venit e Rubro concha Erycina salo, et Tyros ostrinos praebet Cadmea colores, cinnamon et multi pistor odoris Arabs

«The Indian ant sends gold from the caves of her mines, and from the Red Sea comes the shell of Venus; Cadmean Tyre purveys her crimson tints, and cinnamon, the Arab distiller of rich scents».

${ }^{21}$ E.Z. Damer, The Female Body in Latin Love Poetry, dissertation 2010:130.

${ }^{22}$ S. J. Harrison, «Drink, suspicion, and comedy in Propertius 1.3 », PCPhS 40 (1994): 1826.

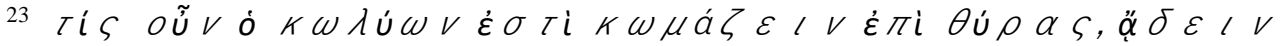
тें $\pi \alpha \rho \alpha k \lambda \alpha \cup \sigma i \theta \cup \rho O V$;

${ }^{24}$ A. K. Leonard, The Social and Political Context for obstruction in Roman Love Elegy, B.A., The University of Georgia, Athens, Georgia, 2004: 27-29.

25 89-90 Agite bibite, festivae fores; potate, fite mihi volentes propitiae.

${ }^{26}$ Plautus's Curculius 147-155:

Phaed. Pessuli, heus pessuli, vos saluto lubens, vos amo, vos volo, vos peto atque obsecro, gerite amanti mihi morem, amoenissumi, fite causa mea ludii barbari, sussilite, obsecro, et mittite istanc foras, quae mihi misero amanti ebibit sanguinem. 


\section{Maria GIANNAKI}

hoc vide ut dormiunt pessuli pessumi

nec mea gratia commovent se ocius.

re spicio, nihili meam vos gratiam facere.

«Bolts, ah, bolts, I greet you gladly :

Take my love and hear my plea,

Hear my prayer, my supplication,

Fairest bolts,ah, favour me.

Change to foreign dancers of me,

Spring, I pray you, spring on high,

Send a wretched man his dear love,

Love that drains his life - blood dry.

Look! They sleep, those bolts most base

Will not budge to do me grace!

You care nothing about doing me grace,

That's plain».

${ }^{27}$ See I.C.Yardley, «The Elegiac Paraclausithyron», Eranos 76,1978:19-34passim, who points out the previous "mediation" of Roman comedy in the admission of Paraclausithyron and custos of the figure in Roman elegy.

${ }^{28}$ I.16.5-6 nunc ego, nocturnis potorum saucia rixis, pulsata indignis saepe queror minibus « today, scarred by the nightly brawls of drunken youths, I oft complain at being battered by ill-bred hands».

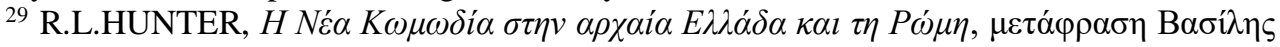

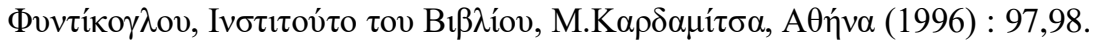

${ }^{30}$ J.B. Debrohun, Roman Propertius and the Reinvention of Elegy, University of Michigan, 2003:126.

${ }^{31}$ S.Viarre Properce Elégies, Paris, C.U.F.,Les Belles Lettres, $2005: 180$ n. 117; R.J.Baker, Propertius I, an Introduction, Translation and Commentary, Warminster, 2000: 144.

${ }^{32} \mathrm{Apart}$ from this elegy we found this motif in many other elegies : I.3.36., I.10.16.,II.5.22., II.6.2, II.6.24.,II.6.37, II.7.9-10., II.9.42., II.14.21., II.20.23., III.7.72., III.25.9-10.

${ }^{33}$ C.Nappa, «Elegy on the Threshold: Generic Self-Consciousness in Propertius 1.16» The Classical World 101, No. 1 (2007): 57-73, esp.57.

${ }^{34}$ I.16.15-16 : ille meos numquam patitur requiescere postes arguta referens carmina blanditia

«He never allows my portals any respite, as with artful blandishment he repeats his serenade».

${ }^{35}$ Quae fueram magnis olim patefacta triumphis,

ianua Patriciae vota Pudicitiae,

cuius inaurati celebrarunt limina currus, captorum lacrimis umida supplicibus 


\section{- Intertextual and Intercultural Dynamics between Roman Comedy and Latin Love Elegy}

«I who of old stood open to welcome splendid triumphs, a door vowed to Patrician Chastity, whose threshold was thronged with gilded chariots and moistened with captives' suppliant tears»».

${ }^{36}$ F.O. Copley, Exclusus Amator. A study in Latin love poetry. Madison, Wisconsin: American Philological Association,Oxford: Blackwell, 1956:123.

${ }^{37}$ Plautus Bacchides 234 sed foris concrepuit nostra: quinam exit foras? «But there goes our door! Wonder who's coming out», Miles Gloriosus 410 sed fores vicini = proxumi crepuerunt. Conticiscam «But our neighbour's door creaked! No more now!», Persa 404 sed ibi concrepuit foris. quisnam egreditur foras? «A noise at the door there, though! Who's coming out, I wonder?» and Terence Andria 682 sed mane; concrepuit a / Glycerio ostium «Hollo, I hear Glycerium's door opening», Heauton Timorumenos 173 ibo adeo hinc intro. sed quid crepuerunt fores «I'll go in at once. Ah, I hear someone opening my door».

${ }^{38}$ ADV. Quid est? COLL. Fores hae fecerunt magnum flagitium modo. ADV. Quid <id> est flagiti? COLL. Crepuerunt clare. ADV. Di te perduint. pone nos recede. COLL. Fiat. ADV. Nos priores ibimus.

«Couns. What is it?

Coll. This door just did something perfectly dreadful.

Couns. Dreadful? What?

Coll. It let out a loud rumble.

Couns. You be damned! Get in the rear!

Coll. All right.

Couns. We'll go ahead».

${ }^{39}$ Verse 158 Leaena: Placide egredere et sonitum prohibe forium et crepitum cardinum «Step out quietly, Planesium dearie, and don't let the door rattle or the hinges grate, or master will find out what we're doing here».

40 87-95 95 Phaed. : Sequere hac, Palinure, me ad fores, fi mi obsequens.

Pal. :Ita faciam. Phaed.:Agite bibite, festivae fores;

potate, fite mihi volentes propitiae.

Pal.: Voltisne olivas [aut] pulpamentum [aut] capparim?

Phaed. : Exsuscitate vostram huc custodem mihi.

Pal.: Profundis vinum: quae te res agitant? Phaed.: Sine.

viden ut aperiuntur aedes festivissumae?

num muttit cardo? est lepidus. Pal. : Quin das savium?

Phaed.: Tace, occultemus lumen et vocem. Pal.: Licet.

«This way, Palinurus, - up to the door- come, oblige me.

All right, all right.

Drink, ye portals of pleasure, drink! Quaff deep, and deign to be propitious unto me!=

$=$ Will ye have some olives, portals, - a croquette - a pickled caper?

Rouse your keeper and send her hither.

You'are wasting the wine! What possesses you?

Unhand me! (as the door moves) See you how it opens - the bower of bliss beyond compare? Hear you a creak from the hinge? Oh, lovely hinge! 


\section{Maria GIANNAKI}

Why don't you kiss it?

Sh-h! Let's hide the light and hold our tongues.

Very well».

${ }^{41}$ Baker, Propertius I, $2000: 148$.

${ }^{42}$ quippe coronatos alienum ad limen amantes

nocturnaeque canes ebria signa morae,

ut per te clausas sciat excantare puellas, qui volet austeros arte ferire viros

«For you will sing of garlanded lovers at another's threshold and the tipsy tokens of midnight vigil, so that he who would artfully outwit stern husbands may learn from you how to charm forth a locked-up woman».

${ }^{43}$ J.P.Boucher, Etudes sur Properce, 1965:421.

${ }^{44}$ II.6.1-6 NON ita complebant Ephyraeae Laidos aedis, ad cuius iacuit Graecia toea fores;

turba Menandreae fuerat nec Thaidos olim

tanta, in qua populus lusit Erichthonius;

nec quae deletas potuit cormponere Thebas,

Phryne tam multis facta beata viris.

«Not thus used they to throng the house of Lais at Corinth, and at her door all Greece lay suppliant; nor did so great a crowd over gather about Menander's Thais, in whom the people of Athens took its pleasure; nor by so many men was Phryne enriched, she whose wealth could have rebuilt ruined Thebes».

D.T.Benediktson, Propertius A Modernist Poet of Antiquity, 1989:26.

${ }^{45}$ «Let me be the dainty, the winged one».

${ }^{46}$ I.16.19-20 cur numquam reserata meos admittis amores, nescia furtivas reddere mota preces?

«Why are you never unbolted to admit my love, incapable of being stirred and passing on my stealthy prayers?»

${ }^{47}$ I.16.33-34 nunc iacet alterius felici nixa lacerto, at mea nocturno verba cadunt Zephyro

« Now she lies cradled in the happy arms of another, while my words fall unheeded on the night wind».

${ }^{48}$ I.16.41-42 at tibi saepe novo deduxi carmina versu, osculaque innixus pressa dedi gradibus

«often have I rather spun you new strains of song and, upon my knees, passionately kissed your steps».

${ }^{49}$ W.S.Anderson, «Hercules Exclusus: Propertius, IV, 9». AJP 85 (1969): 1-12.

${ }^{50}$ F.Cairns. «Propertius 4.9: 'Hercules Exclusus' and the Dimensions of Genre» Gotthard Karl Galinsky, ed., The Interpretation of Roman Poetry: Empiricism or Hermeneutics? Frankfurt 1992: 65-95.

${ }^{51}$ IV.9.49-50 mollis et hirsutum cepit mihi fascia pectus, et manibus duris apta puella fuit «and a soft breastband once confined my shaggy chest, and for all my rough hands I proved a likely girl». 


\section{- Intertextual and Intercultural Dynamics between Roman Comedy and Latin Love Elegy}

${ }^{52}$ I.1.1. Cynthia prima suis miserum me cepit ocellis «Cynthia first with her eyes ensnared me, poor wretch».

${ }^{53}$ Charinus Sumne ego homo miser, qui nusquam bene queo quiescere? si domi sum, foris est animus, sin foris sum, animus domist. ita mi in pectore atque in corde facit amor incendium «Oh, I am miserable! I can't be comfortable anywhere! If I'm at home, my thoughts are out; and if I'm out, my thoughts are at home! Such flames of love as my heart and breast are in!».

${ }^{54}$ pariter hos perire amando video, uterque insaniunt. viden ut misere moliuntur? nequeunt complecti satis «I see that they're both alike, dying of love, both insane. D'ye see how they're working, poor things? They can't hug hard enough!».

${ }^{55}$ Acr. Si amavit umquam aut si parem sapientiam habet ac formam, per amorem si quid fecero, clementi animo ignoscet.

Pal. Vt, quaeso, amore perditast tuo misera. Pyrg. Mutuom fit.

«Acr. If he has ever loved, or if he has an understanding equal to his beauty, he will be compassionate and pardon me for what I shall have done through the love of him!

Pal. For mercy's sake, sir, how desperately the poor creature does dote on you!

Pyrg. And I on her!».

${ }^{56}$ PA. credo, ut fit, misera prae amore exclusti hunc foras. «Quite so, quite natural; poor lady, it was love made you shut the door against him».

57 itane obstinate operam dat ut me a Glycerio miserum abstrahat? « Is he stubbornly bent on making me miserable by tearing me from Glycerium?»

${ }^{58}$ I.1.7. ei mihi, iam toto furor hic non deficit anno «poor me, for a whole year now this frenzy has not abated».

${ }^{59}$ I.1.2. contactum nullis ante cupidinibus «that had previously been untouched by desire».

${ }^{60}$ Verse 19 «for in the wake of love commonly come all these ills-care, sorrow and excessive display» and 870 «Care, misery, tribulation, tears, laments».

${ }^{61}$ Verses 307-308 «Byrria "There now, how much better to set yourself to clear this passion out of your thoughts than say what can only inflame your desires and do no good". Char. When you're well it's easy to give sound advice to a sick man. Take my place and you'll think differently » and 559 "Simo: Now look here, that's just what I beg you to prevent. While there's a chance, while this passion is barred by insults, before these women's wicked ways and counterfeit tears recall his love - sick mind to pity, let us give him a wife. I hope that the tie of association and marriage with a gentlewoman will make it easy for him to escape from this sea of evil».

${ }^{62}$ I.1.9-10 : Milanion nullos fugiendo, Tulle, labores saevitiam durae contudit Iasidos «It was, friend Tullus, by shrinking from no hardship that Milanion broke down the cruelty of harsh Atalanta».

${ }^{63}$ Verses 82-83 Amens amansque ut animum offirmo meum « lovesick lunatic though I was, I summoned my resolution and declared that I would go on a trading trip..».

${ }^{64}$ Line 218 nam inceptiost amentium, haud amantium «why, theirs is more like a scheme of lunatics than of lovers». 


\section{Maria GIANNAKI}

${ }^{65}$ I.1.21-22 : en agedum dominae mentem convertite nostrae, et facite illa meo palleat ore magis! «alter the heart of my mistress and see that she turn paler than this cheek of mine».

${ }^{66}$ Also elegies I.5.21, I.9.17, I.13.7

${ }^{67}$ Line 51-58 meus oculus, mea Selenium, numquam ego te tristiorem vidi esse. quid, cedo, te obsecro tam abhorret hilaritudo? neque munda adaeque es, ut soles-hoc sis vide, ut petivit suspiritum alte- et pallida es. eloquere utrumque nobis, et quid tibi est et quid velis nostram operam, ut nos sciamus. noli, obsecro, lacrumis tuis mi exercitum imperare «Why, my darling, my dear, Selenium, I've never seen you looking more melancholy. For mercy's sake, tell me, why are you and cheerfulness such strangers? And you don't look as smart as usual - just see, that deep, deep sigh! - and you're pale, too. Come, tell us two things - what the trouble is, and how you want us to help you - so that we may understand matters. Don't cry, please, and bring an attack on me, too».

${ }^{68} \ll$ Pal. You and some young stranger, so he told me, ma'am.

Scel. Yes, by heaven, so I did!

Phil. You saw me? Me?

Scel. Indeed I did, by heaven, and with these eyes!

Phil. Eyes which you will part with, I warrant, since they see more than they do see.

Scel. I won't be scared out of having seen what I did see, never, by heaven.

${ }^{69}$ Persa verse 24 «I have been wounded in the lists of Love! My heart has been transfixed by Cupid's shaft!».

${ }^{70}$ Prop. II. 5. 21, II. 15. 17, IV. 5. 31.

71 859-860: Nihil est lucri quod me hodie facere mavelim, quam illum cubantem cum illa opprimere, ambo ut necem.

72 522-527: di me omnes, magni minuti, et etiam patellarii faxint, ne ego <dem vivae> vivos savium Selenio, nisi ego teque tuamque $\sim$ filiam meque hodie obtruncavero, poste autem cum primo luci cras nisi ambo occidero, et equidem hercle nisi pedatu tertio omnis efflixero, nisi tu illam remittis ad me.

73 925- 929 : Meosne ante oculos ego illam patiar alios amplexarier? mortuom hercle me hodie satiust. apstine hoc, mulier, manum, nisi si te mea manu ui in machaera et hunc vis mori. PHRON. Nil halapari satiust, miles, si te amari postulas; auro, hau ferro deterrere potes, <hunc〉 ne amem, Stratophanes.

${ }^{74}$ II.5.21-26 nec tibi periuro scindam de corpore vestis, nec mea praeclusas fregerit ira fores, nec tibi conexos iratus carpere crinis, nec duris ausim laedere pollicibus: rusticus haec aliquis tam turpia proelia quaerat, cuius non hederae circuiere caput 


\section{- Intertextual and Intercultural Dynamics between Roman Comedy and Latin Love Elegy}

«I shall not tear the clothes from your perjured body, nor let my anger shatter your locked door, nor bring myself in my rage to pull at your plaited hair, nor hurt you with brutal thumbs. Let some boorish clown pick these vulgar quarrels, one whose head no ivy has ever circled».

${ }^{75}$ II.5.27-30 scribam igitur, quod non umquam tua deleat aetas, 'Cynthia, forma potens; Cynthia, verba levis.' crede mihi, quamvis contemnas murmura famae, hic tibi pallori, Cynthia, versus erit «So I shall write what you can never live down or cancel: 'Cynthia, mighty beauty; Cynthia, fickle in speech'. Believe me, however much you disregard the mutterings of gossip, this is a verse which will make you pale».

${ }^{76}$ Elegy III.8.9 nimirum veri dantur mihi signa caloris «you are without question giving me tokens of true ardour».

${ }^{77}$ The figure of the old procurer woman is traced in elegies I. 5 and II. 6 of Tibullus and eminently in elegy IV. 5 of Propertius which constitutes the basic model and intertext of Amores. 1. 8, see below.

${ }^{78}$ J.C. Mckeown, Ovid : Amores. A Commentary on Book I. Vol.2, editions Francis Cairns (1987): 198-199.

${ }^{79}$ 177-186 CLEAR. Non tu scis? quae amanti parcet, eadem sibi parcet parum. quasi piscis, itidemst amator lenae: nequam est, nisi recens;

is habet sucum, is suavitatem, eum quo vis pacto condias,

vel patinarium vel assum, verses quo pacto lubet:

is dare volt, is se aliquid posci, nam ibi de pleno promitur;

neque ille scit quid det, quid damni faciat: illi rei studet.

volt placere sese amicae, volt mihi, volt pedisequae,

volt famulis, volt etiam ancillis; et quoque catulo meo

subblanditur novos amator, se ut quom videat gaudeat.

vera dico: ad suom quemque hominem quaestum esse aequomst callidum.

«You miss the point? The lady that spares her lover spares herself too little. Lovers are the same as fish to us- no good unless they're fresh. Your fresh ones are juicy and sweet; you can season them to taste in a stew, bake them, and turn them every day. Your fresh one wants to give you things, wants to be asked for something: in his case it all comes from a full cupboard, you see; and he has no idea what he's giving, what it costs him. This is his only thought: he wants to please, please his girl, please me, please the maid servants, too: yes, the new lover makes up to my little dog, even, so that he may be glad to see him. This is the plain truth: every one ought to keep a sharp eye for the main chance».

${ }^{80}$ Verse 175 Philolaches, the son of Teopropides : «There now! I'll certainly make you a present of something, Scapha, for those words. I won't let you praise the girl that pleases me, for nothing».

${ }^{81}$ Many close parallels are found in Plautus and Terence. For the meretrix as teacher, cf. Plautus Bacch. 163-65 (the pupil is a rudis adulescens); Truc. 132, 735 ff.; Terence Hec. 203 ff.; for the lena as teacher, cf. P1. As. i. 3. especially $177 \mathrm{ff} ., 215$ if. (ironical 


\section{Maria GIANNAKI}

revelations of praecepta to an adulescens), $504 \mathrm{ff}$. (to a meretrix); Cist. $38 \mathrm{ff} ., 78-81$ (to a meretrix); Terence Eun. 233 ff.; the older meretrix instructing a younger, Most. i. 3, especially 171, 186, 246, 265-78; Poen. 216, 233-329; the peritus adulescens instructing a friend, Tr. 665-78, etc.

${ }^{82}$ Propertius I. 8, II. 16, II. 23, III. 13, IV. 5.

${ }^{83}$ nam istae veteres, quae se unguentis unctitant, interpoles, vetulae, edentulae, quae vitia corporis fuco occulunt, ubi sese sudor cum unguentis consociavit, ilico itidem olent, quasi cum una multa iura confudit cocus

«Sc. Why, those ancient dames that pickle themselves in perfume, made-up crones without any teeth, that try to paint away their bodily blemishes - as soon as their perfume and perspiration come together, they smell the same as when a cook combines a lot of sauces».

${ }^{84}$ his animum nostrae dum uersat Acanthis amicae per tenuem ossa sunt numerata cutem

«with Acanthis thus working on my sweetheart's mind, the bones could be counted through my shrunken skin». K. Gutzwiller in «The Lover and the Lena: Propertius 4.5» Ramus 14.2 (1985): 105 , like her predecessors, places the elegy in the context of its antecedents in comedy, mime, and epigram.

${ }^{85}$ IV.5.41-46, 29-30 nec te Medeae delectent probra sequacis (nempe tulit fastus ausa rogare prior), sed potius mundi Thais pretiosa Menandri, cum ferit astutos comica moecha Getas in mores te uerte uiri: si cantica iactat, $i$ comes et uoces ebria iunge tuas ... et simulare uirum pretium facit: utere causis! maior dilata nocte recurret amor

«Let not the abuse of importunate Medea please you (naturally, she who presumed to ask first was repaid with rejection) but rather expensive Thais in urbane Menander's play, where the stage harlot outsmarts the cunning slave. Adapt yourself to the ways of the man: if he strikes up a song, accompany him and join your drunken voice to his...To feign a regular lover also raises your price: invent excuses! Postpone a night, and love will return with increased passion».

${ }^{86}$ G.Hutchinson, Propertius Elegies Book IV, Cambridge Greek and Latin Classics, 2006:146.

${ }^{87}$ J.P. Boucher, Etudes sur Properce, 1965:86.

${ }^{88}$ 290-294 Omnibus modis qui pauperes sunt homines miseri vivont, praesertim quibus nec quaestus est, nec didicere artem ullam: necessitate quidquid est domi id sat est habendum.

nos iam de ornatu propemodum ut locupletes simus scitis:

hisce hami atque haec harundines sunt nobis quaestu et cultu

«Poor folks have a hard life of it every way, especially if they haven't any regular business and never learnt a trade. Whatever they have, that has simply got to do for'em. 


\section{- Intertextual and Intercultural Dynamics between Roman Comedy and Latin Love Elegy}

As for us, you can just about tell what plutocrats we are from one look at our get-up. These hooks and rods here - that's how we subsist and flourish».

${ }^{89}$ 554-558 nam hoc qui sciam, ne quis id quaerat ex me, domist qui facit improba facta amator, qui bona sua pro stercore habet, foras iubet ferri, metuit $<$ ne> apud nos <non> mundissimum sit; puras sibi esse volt aedis: domi quidquid habet, eicitur exo

«Just to save anyone's asking me how I know this, we've got a lover at home, and the vile things he does do! He takes his own property for dung, has it carried off outside, treads our being the least bit defiled by it. He wants his house to be pure».

${ }^{90}$ Debrohun, Roman Propertius, 2003:20.

${ }^{91}$ IV.1.71-72 quo ruis imprudens ? Fuge discere fata, Properti! non sunt a dextro condita fila colo «Whither do you hurry so thoughtlessly? Seek not to learn your fate, Propertius! From no auspicious distaff have its threads been spun».

${ }^{92}$ IV.1.121-122 Umbria te notis antiqua Penatibus edit -mentior? an patriae tangitur ora tuae? «Ancient Umbria bore you in an illustrious home-do I lie, or have I hit upon the borders of your native land?».

${ }^{93} 135-136$ «Now you must compose Elegy, a fallacious task [ or pellax opus alluring task, according to the edition G.P.Goold, Loeb 1990 ] ( here lies your camp), so that the rest of the throng will write after your example an alluring».

${ }^{94}$ Ovidius, Amores I.15.17-18 Dum fallax servus, durus pater, inproba lena Vivent et meretrix blanda, Menandros erit «As long as tricky slave, hard father, treacherous bawd, and wheedling harlot shall be found, Menander will endure».

${ }^{95}$ 52-55 quid? contraxistis frontem, quia tragoediam dixi futuram hanc? deus sum, commutavero. eandem hanc, si voltis, faciam ex tragoedia comoedia ut sit omnibus isdem vorsibus «What ? Frowning because I said this was to be a tragedy? I am a god: I'll transform it. I'll convert this same play from tragedy to comedy, if you like, and never change a line». ${ }^{96}$ Voir Alain Deremetz, Le miroir des Muses-Poétiques de la reflexivité, Lille 1995 : 175238 where the comic element is presented as an exemple of reflexivity.

${ }^{97}$ P.Grimal L'amour à Rome, 1963 :202-203.

${ }^{98}$ M.Gazeau, Le tombeau de Cynthia: Mythes, Fictions et Ironie dans le livre IV des Elégies de Properce, thesis Paris III- Sorbonne Nouvelle, 2008 : 248.

\section{Bibliography Editions}




\section{Maria GIANNAKI}

-Butler, H.E. and Barber, E.A. 1933. The elegies of Propertius, Oxford.

-Goold, G.P. 1990. Propertius Elegies, edited and translated by G.P.Goold, Harvard University Press, Cambridge, Massachussets, London.

-Hamilton Fyfe, W. 1965. Aristote, The Poetics, Longinus On the Sublime, Demetrius On Style, The Loeb Classical Library, London, Harvard University Press.

-Nixon, P. Plautus, in five volumes, The Loeb Classical Library,

1961. Volume I (Amphitruo or Amphitryon, Asinaria or The Comedy of Asses, Aulularia or The Pot of Gold, Bacchides or The Two Bacchises, Captivi or The Captives)

1965. Volume II (Casina, Cistellaria or The Casket Comedy, Curculio, Epidicus, Menaechmi or The Two Menaechmuses)

1957. Volume III (Mercator or The Merchant, Miles Gloriosus or The Braggart Warrior, Mostellaria or The Haunted House, Persa or The Persian)

1959. Volume IV (Poenulus or The Little Carthaginian, Pseudolus, Rudens or The Rope)

-Sargeaunt, J. Terence,

1964. Volume I (The Lady of Andros, The Self - Tormentor, The Eunuch), Harvard University Press.

1959. Volume II (Phormio, The Mother-in-law, The Brothers).

-Showerman, G. 1963. Ovid Heroides and Amores, The Loeb Classical Library, London, Harvard University Press.

-Trypanis, C.A. 1975. Callimachus, Aetia-Iambi-Lyric Poems - HecaleMinor epic and elegiac poems- and other fragments, text, translation and notes, The Loeb Classical Library, London, Harvard University Press.

-Viarre, S. 2005. Properce Elégies, Paris, C.U.F., Les Belles Lettres.

\section{Works Cited}




\section{- Intertextual and Intercultural Dynamics between Roman Comedy and Latin Love Elegy}

-Allison, J. 1984. «The Cast of Characters in Propertius 4.7. »CW 77.6: 355-58.

-Anderson, W. S.1969. «Hercules Exclusus: Propertius, IV, 9. » AJP 85: 112.

-Anderson, W. S.1992. «The Limits of Genre: Response to Francis Cairns» Gotthard Karl Galinsky, ed., The Interpretation of Roman Poetry: Empiricism or Hermeneutics? : 96-103. Frankfurt.

-Anrnott, G. 1975. «The Modernity of Menander», Greece and Rome 22 : 140-155.

-Baker, R.J. 2000. Propertius I, with an Introduction, Translation and Commentary, Warminster.

-Benediktson, D.T. 1989. Propertius A Modernist Poet of Antiquity, Carbonsdale and Edwardsville.

-Besnier, R. 1979. «Properce et le premier échec de la législation démographique d'Auguste», RHD 57 : 191-203.

-Boucher, J.P. 1965. Etudes sur Properce, Problèmes d'Inspiration et d'Art, Paris, Editions E. de Boccard.

-Boyancé, P.1956. «Properce» L'influence grecque sur la poésie latine de Catulle à Ovide, Entretiens sur l'Antiquité Classique, t.II, Fondation Hardt, Vandoeuvres-Geneve.

-Cairns, F. 1979. Tibullus: A Hellenistic Poet at Rome. Cambridge: Cambridge UP.

-Cairns, F. 1992. «Propertius 4.9: 'Hercules Exclusus' and the Dimensions of Genre» Gotthard Karl Galinsky, ed., The Interpretation of Roman Poetry: Empiricism or Hermeneutics? 65-95. Frankfurt.

-Copley, F.O. 1956. Exclusus Amator. A study in Latin love poetry. Madison, Wisconsin: American Philological Association, Oxford: Blackwell.

-Dee, J. 1978. «Elegy 4.8: A Propertian Comedy» TAPA 108: 41-53.

-Della Corte, F. 1991 «Doctus Roscius», Studi G. Monaco: 795-799, Palerme. 


\section{Maria GIANNAKI}

-Deremetz, Al. 1995. Le miroir des Muses-Poétiques de la reflexivité, Lille.

-Debrohun, J.B. 2003, Roman Propertius and the Reinvention of Elegy, University of Michigan.

-Fedeli, P. 1987. «Acanthis e la sete dei morti» Renato Raffaelli, ed., Rappresentazioni della morte,: 93-129. Urbino

-Gazeau, M. 2008. Le tombeau de Cynthia: Mythes, Fictions et Ironie dans le livre IV des Elégies de Properce, thesis, Paris III- Sorbonne Nouvelle.

-Grimal, P. 1963. L' amour à Rome, Paris.

-Gutzwiller, K. 1985. «The Lover and the Lena: Propertius 4.5» Ramus 14.2: $105-15$.

-Harrison, S. J. 1994. «Drink, suspicion, and comedy in Propertius 1.3», PCPhS 40: 18-26.

-Howard, J. 1992. «The Death of the Paraclausithyron: Propertius 1,16», In the two worlds of the poet: New Perspectives on Vergil, ed. R.Wilhelm and H.Iones:303-309.

-Hubbard, M. 1974. Propertius, London, Duckworth.

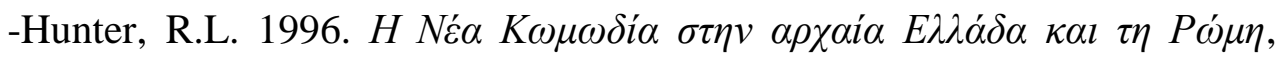

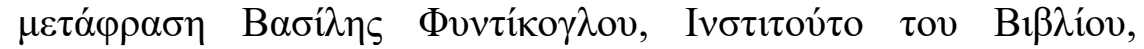
M.K $\alpha \rho \delta \alpha \mu i ́ \tau \sigma \alpha$, A $\theta \eta \dot{v} \alpha$.

-Hutchinson, G. 2006. Propertius Elegies Book IV, Cambridge Greek and Latin Classics.

-James, S. L. 1998 «Introduction: Constructions of Gender and Genre in Roman Comedy and Elegy» Helios 25.1 : 3-16.

-James, S.L. 2006. «A courtesan's choreography : Female Liberty and Male Anxiety at the Roman Dinner Party» Prostitutes and Courtesans in the Ancient World, edited by C.Faraone and Laura K. McClure.

-King, J.L. 1969. Studies in Verbal Repetition in the Monobiblos of Propertius Diss.U. of Colorado. 
- Intertextual and Intercultural Dynamics between Roman Comedy and Latin Love Elegy

-Leonard, A. K. 2004. The Social and Political Context for obstruction in Roman Love Elegy, B.A., The University of Georgia, Athens, Georgia.

-Luck, G. 1969. The Origin of the Latin Love Elegy, ed.2 London.

-Mckeown, J.C. 1987. Ovid: Amores. A Commentary on Book I. Vol.2, editions Francis Cairns.

-Nappa, C. 2007. «Elegy on the Threshold: Generic Self-Consciousness in Propertius $1.16 »$ The Classical World 101, No. 1: 57-73. -Postgate, J.P. 1905. Select Elegies of Propertius, London.

-Traill, A. 2001. «Menander's "Thais" and the Roman Poets» Phoenix Vol. 55: 284-303.

-Veyne, P. 1983. L'élégie érotique à Rome, Paris.

-Wheeler, A.L. 1910. «Erotic Teaching in Roman Elegy and the Greek Sources» Classical Philology p .444., Vol. 5, No. 4 : 440-450.

-Yardley, I.C.1972. «Comic Influences in Propertius » Phoenix Vol. 26, No. 2:134-139.

-Yardley, I.C.1978. «The Elegiac Paraclausithyron», Eranos 76:19-34.

-Yardley, I.C. 1979. «The door and the lover: Propertius I.16» PLLS 3: $155-162$. 